\title{
MEDIA BUKU CERITA: EFEKTIFITASNYA UNTUK MENINGKATKAN HASIL BELAJAR BAHASA INDONESIA SISWA SEKOLAH DASAR
}

\author{
Dicky Surachman \\ Universitas Nahdlatul Ulama Cirebon, Jalan Sisingamangaraja No. 33, Lemahwungkuk, \\ Panjunan, Kec. Lemahwungkuk, Kota Cirebon, Jawa Barat 45111 \\ surachmandicky@gmail.com
}

Diterima 29 Juni 2020, disetujui 05 Oktober 2020, diterbitkan 20 Oktober 2020

Pengutipan: Nama (2020). Media Buku Cerita: Efektifitasnya untuk Meningkatkan Hasil Belajar Bahasa Indonesia Siswa Sekolah Dasar. Gema Wiralodra, Vol 11, No 2, Hal 180189, Oktober 2020

\begin{abstract}
ABSTRAK
Tujuan penelitian ini untuk mengetahui efektifitas penggunaan media buku cerita dalam meningkatkan hasil belajar Bahasa Indonesia siswa Sekolah Dasar. Subyek penelitian ini yakni seluruh siswa kelas IV Sekolah Dasar Negeri 2 Pekantingan yang berjumlah siswa 30 siswa. Untuk melihat efektifitas media buku cerita menggunakan penelitian menggunakan penelitian eksperimen. Sedangkan uji statistic yang digunakan yakni uji t menggunakan SPSS versi 22. Hasil penelitian ini menunjukkan bahwa ada pengaruh dan peningkatan hasil belajar bahasa indonesia siswa yang signifikan antara kelas eksperimen dan kelas kontrol. Hal ini disebabkan karena respon siswa terhadap pembelajaran Bahasa Indonesia menggunakan media buku cerita menunjukkan kategori yang kuat. Hal ini dapat dilihat pada rekapitulasi hasil angket hampir seluruh siswa memberikan respon positif. Selain itu, hasil belajar kelas eksperimen dengan menggunakan media buku cerita yang diterapkan dalam pembelajaran Bahasa Indonesia terbukti berpengaruh positif terhadap peningkatan hasil belajar dibandingkan dengan pembelajaran konvensional.
\end{abstract}

Kata Kunci: Bahasa Indonesia, Media Buku Cerita, Hasil Belajar

\begin{abstract}
The purpose of this study was to determine the effectiveness of using storybook media in improving Indonesian learning outcomes. The research subjects of this study were all fourth-grade students of SD Negeri 2 Pekantingan, totaling 30 students. This research is experimental research. This test was carried out using SPSS version 22. The results of this study indicate that there are a significant influence and increase in student learning outcomes between the experimental class and the control class. This is because the student's response to Indonesian language learning using storybook media shows a strong category. This can be seen in the recapitulation of the results of the questionnaire, almost all students gave positive responses. In addition, the learning outcomes of the experimental class using storybook media that are applied in Indonesian language learning are proven to have a positive effect on improving learning outcomes compared to conventional learning.
\end{abstract}

Keywords: Indonesian Language, Storybook Media, Learning Outcomes

\section{PENDAHULUAN}

Mata pelajaran Bahasa dan Sastra Indonesia merupakan kualifikasi kemampuan minimal siswa yang menggambarkan penguasaan pengetahuan, 
keterampilan berbahasa, dan sikap positif terhadap bahasa dan Sastra Indonesia (Rafida, dkk, 2013). Standar kompetensi ini merupakan dasar bagi siswa untuk memahami dan merespon situasi lokal, regional, nasional, dan global (Delvia, 2017). Bahasa Indonesia mempunyai ruang lingkup dan tujuan yang menumbuhkan kemampuan mengungkapkan pikiran perasaan dengan menggunakan bahasa yang baik dan baku, karena bahasa merupakan modal terpenting bagi manusia (Rosiana \& Mulyani, 2017).

Berdasarkan hasil Observasi yang dilakukan di SDN Kertasemaya 1 kelas $\mathrm{V}$, pada pelajaran Bahasa Indonesia materi Menyimak dapat disimpulkan diantaranya siswa selalu ramai atau ribut saat pembelajaran berlangsung,sehingga konsentrasi siswa tidak terfokus, keberadaan guru pada waktu pembelajaran kurang mendapat perhatian dari siswa. Kendala pembelajaran menyimak adalah siswa sulit memahami isi dari cerita, kemudian media yang diterapkan oleh guru dalam mata pelajaranbahasa indonesia materi menyimak yaitu dengan menggunakan metode ceramah dan bacaan yang sudah ada di buku penunjang saja,dikarenakan guru masih belum menemukan cara yang tepat untuk pembelajaran menyimak. Selain itu hasil belajar siswa masih banyak yang belum memenuhi KKM dari jumlah siswa 30 yang lulus $40 \%$ dan yang tidak lulus $60 \%$. Sehingga perlu adanya solusi yang tepat. Salah satu solusi untuk membangun pembelajaran yang lebih inovatif adalah dengan menggunakan media.

Selain itu, berdasarkan penelitian yang relevan terkait dengan penggunaan cerita bergambar pada topik menyimak bisa dilihat dari hasil penelitiannya Kurniawati \& Koeswanti (2020) yang menyimpulkan bahwa pengembangan media buku cerita bergambar dapat meningkatkan kemampuan membaca siswa sekolah dasar. Selain itu hasil penelitiannya Emosda (2017) yang menyimpulkan bahwa pengaruh penggunaan buku cerita bergambar terhadap motivasi belajar pada siswa sekolah dasar. Hal yang sama juga diungkapkan dari hasil penelitiannya Mahsun \& Khoiriyah (2019) yang mengungkapkan bahwa penggunaan media Big Book dapat Meningkatkan Keterampilan Membaca Siswa Madrasah Ibtidaiyah. Sedangkan hasil penelitiannya Nugraheni, Harsiati, \& Qohar (2019) menyimpulkan bahwa media buku cerita dapat meningkatkan kemampuan membaca dan menulis siswa sekolah dasar. 
Seiring dengan berkembangnya ilmu pengetahuan dan teknologi, pendidikan dapat di lakukan melalui media apa saja baik media massa, buku, majalah, poster, televisi, internet dan lain sebagainya. Salah satu media yang belum begitu banyak di gunakan dan di kembangkan dalam proses belajar mengajar di sekolah adalah media buku cerita. Buku cerita termasuk da media yang mempunyai sifat sederhana, jelas dan mudah di pahami. Oleh karena itu buku cerita dapat menjadi media pembelajaran yang informatif dan edukatif.Menurut Sudjana dan Rivai, (2011: 07) "Media sebagai salah satu komponen dari pengajaran yang sangat berpengaruh terhadap proses pembelajaran. Dengan adanya media yang mendukung dalam proses pembelajaran, akan mampu meningkatkan kualitas hasil belajar siswa". Media sangat di perlukan untuk proses belajar mengajar agar bisa menciptakan suasana kelas yang lebih kreatif dan meningkatkan hasil belajar siswa.

Hal yang di harapkan dalam pembelajaran, media buku cerita dapat meningkatkan siswa untuk menyimak cerita sehingga pada akhirnya mampu meningkatkan hasil belajar siswa. Berdasarkan masalah di atas maka peneliti merumuskan masalah sebagai berikut:

1) Bagaimana pengaruh media buku cerita materi menyimak terhadap hasil belajar kelas V SDN Kertasemaya 1 ?

2) Bagaimana respon siswa kelas V SDN Kertasemaya 1 terhadap penggunaan media buku cerita materi menyimak?

3) Bagaimana proses pembelajaran menggunakanmedia buku cerita materi menyimak kelas V SDN Kertasemaya 1 ?

\section{METODE PENELITIAN}

Berdasarkan tujuan penelitian yang ingin dicapai yaitu untuk mengetahui apakah terdapat pengaruh media buku cerita terhadap hasil belajar siswa mata pelajaran Bahasa Indonesia, maka dalam penelitian ini peneliti menggunakan metode eksperimen. Subyek penelititan ini adalah seluruh siswa kelas IV SD Negeri 2 Pekantingan Tahun Pelajaran 2016/2017 yang berjumlah siswa 30 siswa. Adapun penarikan sampel dalam penelitian ini Sampling Jenuh. Sugiono (2015: 124), Sampling Jenuh adalah teknik penentuan sampel bila semua anggota 
populasi digunakan sebagai sampel, sedangkan Riduwan (2013: 64) mengatakan sampel jenuh adalah teknik pengambilan sampel apabila semua populasi digunakan sebagai sempel dan dikenal juga dengan istilah sensus. Adapun sampel yang digunakan dalam penelitian ini adalah seluruh siswa kelas V SD Negeri 2 Pekantingan yang berjumlah30 siswa. Instrumen yang digunakan dalam penelitian ini terdiri atas dokumen dan instrumen pengumpulan data, di antaranya yaitu:

Tes

Suharsimi (2013:193), menjelaskan bahwa "tes adalah serentetan pertanyaan atau latihan serta alat lain yang digunakan untuk mengukur ketrampilan, pengetahuan intelegensi, kemampuan atau bakat yang dimiliki oleh individu atau kelompok".

\section{Angket (kuesioner)}

Sugiyono(2015: 305), “Kuesioner adalah merupakan teknik pengumpulan data yang dilakukan dengan cara memberi seperangkat pertanyaan atau pernyataan tertulis kepada responden untuk dijawabnya". Angket yang digunakan peneliti diberikan pada kelas eksperimen yang pembelajarannya menggunakan metode demontrasi. Tujuannya adalah untuk mengetahui respon siswa terhadap pembelajaran bahasa indoenesia dengan metode pembalajaran demontrasi dan penyebaran angket diberikan setelah kegiatan postes.

\section{Observasi}

Hadi Sutrisno (Sugiyono:2015:203) mengemukakan bahwa, observasi merupakan suatu proses yang kompleks, suatu proses yang tersusun dari berbagai proses biologis dan psikologis". Dua diantara yang terpenting adalah prosesproses pengamatan dan ingatan teknik pengumpulan data dengan observasi digunakan bilapenelitian berkenaan dengan prilaku manusia, proses kerja, gejalagejala alam dan bila responden yang diamati tidak terlalu besar.

Observasi merupakan alat pengamatan yang digunakan untuk melihat dan mengukur aktivitas guru dan siswa, serta interaksi antara guru dan siswa selama proses pembelajaran berlangsung. Observasi dilakukan dengan bantuan obeserver dan bertujuan untuk melihat perkembangan proses pembelajaran, kekurangan yang terjadi dan kendala-kendala yang dihadapi selama proses pembelajaran. 


\section{Uji Hipotesis}

Setelah melakukan uji normalitas, homogenitas dan linierlitas maka langkah berikutnya adalah melakukan regresi untuk mengetahui hubungan atau pengaruh antara dua variabel dan uji - $\mathrm{t}$ untuk mengetahui ada atau tidak adanya perbedaan antara dua buah data.

\section{Uji t}

Uji t digunakan untuk mengetahui ada atau tidak adanya perbedaan antara dua buah data. Rumus yang digunakan adalah $t_{\text {hitung }}=\frac{\bar{x}_{1}-\bar{x}_{2}}{\sqrt{\frac{(n-1) S_{1}^{2}+(n-1) S_{2}^{2}}{n_{1}+n_{2}-2}\left(\frac{1}{n_{1}}+\frac{1}{n_{2}}\right)}}$

Sedangkan menghitung nilai varians kelompok

$S^{2}=\sum \frac{\left(X_{1}-X_{2}\right)^{2}}{n-1}$

Hipotesis :

$\mathrm{H}_{0}$ : Jika tidak ada perbedaan nilai rata-rata antara

kelas eksperimen dan kelas kontrol

$\mathrm{H}_{1}$ : Jika ada perbedaan nilai rata-rata antara

kelas eksperimen dan kelas kontrol

Jika,

$\mathrm{t}_{\text {tabel }} \geq \mathrm{t}_{\text {hitung, }}$ maka $\mathrm{H}_{0}$ diterima dan $\mathrm{H}_{1}$ ditolak

$\mathrm{t}_{\text {tabel }}<\mathrm{t}_{\text {hitung, }}$ maka $\mathrm{H}_{0}$ ditolak dan $\mathrm{H}_{1}$ diterima

Keterangan:

$\bar{x}_{1}$ : rata-rata nilai kelompok eksperimen

$\bar{x}_{2}$ : rata-rata nilai kelompok kontrol

$S_{1}^{2}$ : standar deviasi pada kelompok eksperimen

$S_{2}^{2} \quad$ : standar deviasi pada kelompok kontrol

$n_{1}$ : banyak subjek kelompok eksperimen

$n_{1}$ : banyak subjek kelompok kontrol

Hasil yang diperoleh dari $t_{\text {hitung }}$ selanjutnya dibandingkan dengan $t_{\text {tabel }}$ yang memiliki derajat kebebasan $\mathrm{dk}=\mathrm{N}_{1}+\mathrm{N}_{2}-2$ dan taraf signifikansi $\alpha=5 \%$. Dalam hal ini tolak hipotesis nol jika $t_{\text {hitung }}>\mathrm{t}_{\text {tabel. }}$ 


\section{Angket}

Angket digunakan untuk mengetahui sejauhmana respon siswa terhadap pembelejaran dengan menggunakan Metode pembalajaran demontrasi.

$$
X_{i}=\frac{a}{n} x 100 \%
$$

Keterangan

$$
\begin{array}{ll}
\mathrm{Xi} & \text { : Pernyataan } \\
\mathrm{a} & \text { : Banyaknya option } \mathrm{x} \text { yang dipilih } \\
\mathrm{n} & \text { : Banyaknya siswa }
\end{array}
$$

a) Mengelompokan siswa yang memilih sangat setuju, setuju, tidak setuju, dan sangat tidak setuju. Baik pernyataan positif maupun negatif

b) Menghitung persentase dari jumlah siswa yang memilih sangat setuju, setuju, tidak setuju, dan sangat tidak setuju. Baik pernyataan positif maupun negatif dengan rumus sebagai berikut:

$$
p=\frac{f}{n} 100 \%
$$

$$
\begin{aligned}
& \text { Keterangan } \\
& \mathrm{p} \quad=\text { persentase jawaban } \\
& \mathrm{f} \quad=\text { frekuensi jawaban } \\
& \mathrm{n} \quad=\text { banyaknya responden }
\end{aligned}
$$

c) Menafsirkan hubungan antara persentase dengan berdasarkan kriteria

Tabel 1 Interprestasi Angket

\begin{tabular}{ccc}
\hline No & Presentasi Skor & Interprestasi \\
\hline 1 & $0 \%-20 \%$ & Respon sangta lemah \\
2 & $21 \%-40 \%$ & Respon lemah \\
3 & $41 \%-60 \%$ & Respon cukup \\
4 & $61 \%-80 \%$ & Respon kuat \\
5 & $81 \%-100 \%$ & Respon sangta kuat \\
\hline
\end{tabular}

\section{HASIL PENILITIAN DAN PEMBAHASAN}

Berdasarkan data yang diperoleh dari catatan lapangan, terdapat beberapa temuan penting yang terjadi selama penelitian berlangsung, diantaranya sebagai berikut : Pada tahap apersepsi, ada siswa yang menjawab dengan benar 
dan ada juga yang menjawab dengan salah tentang menyimak cerita, karena siswa tidak fokus untuk mendengarkan. Pada tahap eksplorasi, anggota kelompok ingin membagi kelompoknya dengan pilihan masing-masing dan tidak ingin dibagi oleh guru sehingga suasana menjadi ribut dan ricuh karena siswa ingin memilih anggota kelompoknya sesuai dengan keinginan siswa. Pada tahap diskusi dan penjelasan konsep, pada saat melaporkan hasil diskusi kelompok tentang menyimak cerita, kelompok Toba dan Kancil hanya mengandalkan siswa yang tulisannya dianggap bagus saja yang ditugaskan untuk melaporkan hasil diskusinya di depan kelas tentang menyimak cerita yang dibacakan guru.

Pada tahap pengembangan dan aplikasi konsep, siswa masih kesulitan dalam menyimpulkan tentang materi yang telah disampaikan karena belum terbiasa sehingga kurang yakin dalam melaporkannya tentang menyimak cerita. Berdasarkan hasil penelitian pada lembar evaluasi kelompok dan individu, diperoleh nilai tertinggi oleh kelompok Sangkuriang yaitu dengan nilai 85, kelompok Malin Kundang 75, kelompok Joko Kendil mendapatkan nilai 75, kelompok Toba mendapatkan nilai 80, sedangkan nilai terendah oleh kelompok Kancil dengan nilai 70, karena mereka belum mampu untuk menjawab benar dengan menggunakan cara secara lengkap. Maka di perolehan nilai rata-rata kelompok adalah 77.00 dan hasil individu diperoleh nilai tertinggi 85 dan nilai terendah 55 dan memperoleh rata-rata individu adalah 66,34.

Penelitian dilakukan dengan menggunakan dua kelas yang dijadikan sebagai sampel penelitian. Satu kelas eksperimen dan kelas lainnya adalah kelas kontrol. Berdasarkan hasil respon siswa terhadap pembelajaran Bahasa Indonesia menggunakan media buku cerita sebesar $76 \%$ menunjukkan kategori yang kuat. Hal ini dapat dilihat pada rekapitulasi hasil angket hampir seluruh siswa memberikan respon positif. Selain itu, hasil belajar kelas eksperimen dengan menggunakan media buku cerita yang diterapkan dalam pembelajaran Bahasa Indonesia terbukti berpengaruh positif terhadap peningkatan hasil belajar dibandingkan dengan pembelajaran konvensional.

Hasil respon siswa menggunakan media buku cerita, memperoleh persentase sebesar 76\%. Hal ini menunjukan bahwa hampir seluruh siswa 
memberikan respon positif terhadap media buku cerita karena termasuk kedalam kategori kuat.

Selain itu berdasarkan hasil uji hipotesis penelitian dapat disimpulkan bahwa pada uji-t diperoleh nilai $t_{\text {hitung }}(0,034)<t_{\text {tabel }}(2,048)$ maka dapat dinyatakan terdapat perbedaan hasil belajar sesudah diterapkannya media buku cerita. Atau dapat diartikan bahwa $\mathrm{H}_{0}$ ditolak, Maka media buku cerita berpengaruh terhadap pokok bahasan menyimak cerita siswa kelas V di SD Negeri Kertasemaya 1 Kecamatan Kertasemaya Kabupaten Indramayu.

\section{KESIMPULAN}

Berdasarkan hasil penelitian dan pengolahan data yang dilakukan peneliti diperoleh kesimpulan sebagai berikut:

1. Menurut beberpa teori dari para ahli yang telah dibahas pada bab II dapat disimpulkan bahwa langkah-langkah proses pembelajaran dengan menggunakan media buku cerita adalah sebagai berikut: (1) Guru dan peneliti terlebih dahulu menyiapkan media buku cerita. (2) Siswa diminta untuk mengkondisikan diri dengan duduk rapih. (3) Guru meminta siswa untuk membuat beberapa kelompok. (4) Guru membacakan cerita anak sebanyak satu kali. (5) Beberapa siswa diminta dengan sukarela untuk menceritakan kembali cerita yang sudah di bacakan, dengan menggunakan bahasa sendiri. (6) Guru memfasilitasi siswa dalam membuat rangkuman, mengarahkan, dan memberikan penegasan pada materi pembelajaran yang telah dicapai. (7) Guru dapat meminta kesan-kesan yang diperoleh siswa dari kegiatan belajar, disamping menyimpulkan materi yang diperoleh dan dihubungkan dengan bahan pengajaran bidang studinya.

2. Hasil respon siswa menggunakan media buku cerita, memperoleh persentase sebesar $76 \%$. Hal ini menunjukan bahwa hampir seluruh siswa memberikan respon positif terhadap media buku cerita karena termasuk kedalam kategori kuat.

\section{DAFTAR PUSTAKA}

Dimyati, dan Mudjiono. (2013). Belajar dan Pembelajaran. Jakarta: Rineka Cipta. 
Hamalik. O(2006). Proses Belajar Mengajar. Jakarta: Bumi Aksara.

Sudjana. N (2012). Penilaian Hasil Proses Belajar Mengajar. Bandung: PT. Remaja Rosda Karya.

Rusmono (2012). Straregi Belajar dengan Problem. Bogor: PT. Ghalia.

Sudjana,rifai (2011) Media Pengajaran. Bandung: Sinar Baru Algensindo.

Daryanto (2013). Media Pembelajaran peranannya sangat penting dalam mencapai tujuan pembelajaran. Yogyakarta: PT. Gava Media.

Sugiyono, (2013). Metode Penelitian Kuantitatif, Kualitatif dan R\&D. Bandung : Alfabeta.

Suharsimi. (2013). Prosedur Penelitian. Jakarta: Rineka Cipta.

Cecep Kustandi, Bambang Sutjipto (2011). Media Pembelajaran; Manual dan digital. Bogor: Ghalia Indonesia.

Sanjaya. Wina (2013). Strategi Pembelajaran Berorientasi Standar Proses Pendidikan. Bandung: Kencana.

Rosiana, S., \& Mulyani, M. (2017). Keefektifan Penggunaan Metode Parafrase dan Metode Inkuiri dalam Pembelajaran Apresiasi Puisi Berdasarkan Minat Baca pada Peserta Didik SMKN 1 Manonjaya dan SMK Nurul Wafa Tasikmalaya. Seloka: Jurnal Pendidikan Bahasa dan Sastra Indonesia, 6(1), 68-73.

Rafida, U., Saringendyati, E., \& Ampera, T. (2013). Apresiasi Sastra Dalam Meningkatkan Gemar Membaca Siswa Sekolah Dasar Di Desa Cogreg Dan Desa Cayur Kecamatan Cikatomas, Kabupaten Tasikmalaya. Dharmakarya, 2(1).

Delvia, D. (2017). Kompetensi Komunikatif Dalam Pembelajaran Bahasa. PENTAS: Pendidikan Bahasa dan Sastra Indonesia, 3(2), 36-46.

Kurniawati, R. T., \& Koeswanti, H. D. (2020). Pengembangan Media Buku Cerita Bergambar Untuk Meningkatkan Kemampuan Membaca Siswa Kelas 1 Sekolah Dasar. Didaktika Tauhidi: Jurnal Pendidikan Guru Sekolah Dasar, 7(1), 29-42.

Emosda, E. (2017). Pengaruh Penggunaan Buku Cerita Bergambar Terhadap Motivasi Belajar Pada Siswa Sekolah Dasar. Jurnal Gentala Pendidikan Dasar, 2(2), 256-274. 
Mahsun, M., \& Koiriyah, M. (2019). Meningkatkan Keterampilan Membaca Melalui Media Big Book Pada Siswa Kelas Ia Mi Nurul Islam Kalibendo Pasirian Lumajang. Bidayatuna: Jurnal Pendidikan Guru Mandrasah Ibtidaiyah, 2(1), 60-78.

Nugraheni, I., Harsiati, T., \& Qohar, A. (2019). Media Buku Cerita untuk Meningkatkan Kemampuan Membaca dan Menulis Siswa Kelas IV Sekolah Dasar. Jurnal Pendidikan: Teori, Penelitian, dan Pengembangan, 4(3), 322-329. 